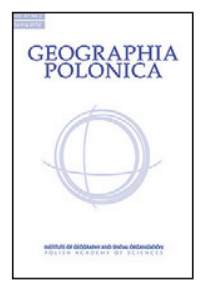

\title{
GREEN INFRASTRUCTURE AS A DETERMINANT OF THE QUALITY OF URBAN LIFE AND A BARRIER TO THE DEVELOPMENT OF A CITY: A CASE STUDY
}

\section{Agnieszka Szczepańska ${ }^{1}$ - Monika Wasilewicz-Pszczółkowska}

Institute of Geography and Land Management

University of Warmia and Mazury in Olsztyn

Prawocheńskiego 15, 10-724 Olsztyn: Poland

${ }^{1}$ Corresponding Author's e-mail: aszczep@uwm.edu.pl

\begin{abstract}
The quality of life and the residential environment in an urban space are considerably influenced by Green Infrastructure. This results from the growing ecological awareness of society and the greater importance attached to the quality of the surrounding environment. Such an approach influences the city's image and its perception with respect to the quality of life. Olsztyn is an example of a city with exceptionally rich natural environmental assets, located in the cleanest region of Poland. The city is developing in line with the "Olsztyn: the Garden City" slogan. The objective of the article is to compare the results of a public opinion poll among city dwellers with respect to the quality of life in terms of natural environment resources.
\end{abstract}

\section{Key words}

green infrastructure $\cdot$ natural attractiveness - quality of life - city's spatial development

\section{Introduction}

Water bodies as well as green areas are the basic components of urbanised structures which enhance the value of space as natural elements of anthropogenic systems. As regards the urban space, the relevant literature indicates multiple benefits of Green Infrastructure (GI). Most frequently, the following benefits are indicated by numerous authors (Tab. 1).
The above-listed benefits of the $\mathrm{Gl}$ in the urban environment contribute, to varying extents, to enhancing the quality of life. Due to the development of environmental awareness, we are able to increasingly notice the significance of the GI. A survey carried out by the Central Statistical Office (GUS) among Polish society revealed that communing with nature, including the landscape, was the favourite way of spending free time devoted to leisure for $7 \%$ of respondents (GUS 2014). 
Table 1. Benefits of Green Infrastructure - literature review

\begin{tabular}{|c|c|c|}
\hline Benefits & Description & Author \\
\hline environmental & $\begin{array}{l}\text { maintaining biodiversity; regulation of humidity; } \\
\text { mitigating climate change effects; regulation of tem- } \\
\text { perature; reception of rainwater and thus flood risk } \\
\text { reduction; air purification; noise reduction; wind force } \\
\text { reduction; shading }\end{array}$ & $\begin{array}{l}\text { Sandström et al. 2006; Matthews et al. } \\
\text { 2015; Barrera et al. 2016; Connop et al. } \\
\text { 2016; Feng 2016; Garmendia 2016; Kim } \\
\text { \& Park 2016; Lanza \& Stone 2016; Lin \& } \\
\text { Lin 2016; Liu et al. 2016; Morakinyo 2016; } \\
\text { Salata \& Savvas 2016; Yiannakou 2016; } \\
\text { Žuvela-Aloise et al. 2016; Wang et al. } \\
\text { 2017; Derkzen et al. } 2017\end{array}$ \\
\hline social & $\begin{array}{l}\text { participation in shaping of the social space; a posi- } \\
\text { tive impact on human wellbeing and health; mood } \\
\text { enhancement; soothing effect for patients and conva- } \\
\text { lescents; increased self-esteem; improved concen- } \\
\text { tration; better interpersonal relationship; reduction } \\
\text { in crime; reduction in domestic violence; increased } \\
\text { comfort of inhabitants' living; development of local } \\
\text { communities; a place for recreation and leisure; } \\
\text { a possibility for contact with the natural environment }\end{array}$ & $\begin{array}{l}\text { Kuo \& Sullivan 2001; Błaszczyk \& Kosmala } \\
\text { 2008; Baycan-Levent \& Nijkamp 2009; } \\
\text { Ernstson 2013; Badiu et al. 2016; Barrera } \\
\text { et al. 2016; Camps-Calvet 2016; Connop } \\
\text { et al. 2016; Kabisch et al. 2016; Sang } \\
\text { 2016; Santos et al. 2016; Paliwoda et al. } \\
\text { 2017 }\end{array}$ \\
\hline aesthetic & $\begin{array}{l}\text { adding variety to the landscape and breaking its } \\
\text { monotony; softening the hard structure of the urban } \\
\text { landscape; creating cosiness and quietness; improv- } \\
\text { ing the architectural outline of buildings; emphasis- } \\
\text { ing traffic routes; adding diversity to architecture; } \\
\text { obstructing ugly views; creating the image of a city; } \\
\text { enhancing tourist and investment attractiveness }\end{array}$ & $\begin{array}{l}\text { Hassan et al. 2005; Böhm 2007; EEA } \\
\text { 2011; Suchocka 2013; Puzdrakiewicz } 2017\end{array}$ \\
\hline cultural & $\begin{array}{l}\text { historic greenery is regarded as national heritage, } \\
\text { and adds a monumental value to areas }\end{array}$ & $\begin{array}{l}\text { Hassan et al. 2005; EEA 2011; Camps- } \\
\text { Calvet } 2016\end{array}$ \\
\hline educational & $\begin{array}{l}\text { every cluster of greenery carries a cognitive value } \\
\text { as regards the observation of local ecosystems }\end{array}$ & Hassan et al. 2005; Puzdrakiewicz 2017 \\
\hline economic & $\begin{array}{l}\text { increasing the value of properties; savings in heating } \\
\text { and cooling costs; greater efficiency and lower rates } \\
\text { of workers' sick leave }\end{array}$ & $\begin{array}{l}\text { Szczepanowska 2012; Maksymiuk 2013; } \\
\text { Suchocka 2013; Barrera et al 2016; Votsis } \\
2017\end{array}$ \\
\hline
\end{tabular}

In another survey focusing on the quality of life, $73.7 \%$ of the Polish society declared being satisfied with the recreation grounds and green areas, with $13.8 \%$ indicating excessive noise, and $11.6 \%$ indicating pollution and other environmental problems in the proximity (GUS 2016, 2017).

In addition to all the above-listed positive aspects of the $\mathrm{Gl}$, it should also be noted that in certain references they carry a negative load as well. Some of the mentioned adverse effects include: attracting hooligans, lowering the safety level and shading of buildings, but these are rather associated with neglected and unmanaged greenery (Lis et al. 2016).
From the perspective of this study, it is the social dimension of the $G \mathrm{l}$, reflected in the increasing quality of life, that is of significance. Quality of life is defined as overall conditions of living being shaped, inter alia, in the environmental dimension, which determine the sense of having one's needs satisfied and life aspirations fulfilled in a particular place and time (Zadrożniak 2016). The quality of life consists of expectations about the surrounding space, including inter alia the possibility for communing with the natural environment in the vicinity of the place of residence (Michniewicz-Ankiersztajn 2014). Growing expectations about the quality of the space that 
we live in result from the increasing environmental awareness which draws our attention to the environmental context of the surroundings. In a narrow sense, environmental awareness is the knowledge, views and ideas about the environment. In broader terms, environmental awareness is a form of social awareness manifesting itself in valuating nature and forming an opinion on the environment as a place where people can live and develop (Papuziński 2006). According to the Hassan et al. (2005) - "Millennium Ecosystem Assessment 2005", ecosystem services affect the quality of our lives in terms of security, the basis for quality of living, health and social relations. With this in mind, people pay attention to the proximity of $\mathrm{Gl}$ because they know its benefits; hence the quality of the surrounding environment is the primary determinant of the quality of life (Mell et al. 2016). However, the fact that our environmental awareness is well-developed does not mean that we care more about the environment (Suárez-Varela et al. 2016), we just expect it to be of high quality without making any contribution.

In order to compare the quality of $\mathrm{Gl}$ and the local residents' opinions on the quality of urban life, a study was carried out in the city of Olsztyn (Poland) to evaluate the effects of $\mathrm{Gl}$ on the spatial development of the city. Olsztyn is an example of an urban settlement above-averagely equipped with GI, which is undoubtedly an asset for the inhabitants and, at the same time, a barrier to the development of the city. This research topic was undertaken to determine the influence of $\mathrm{Gl}$ on the city and its residents and to demonstrate that, whenever possible, Gl development should not be an accidental process. Green infrastructure can affect the quality of urban life and partially inhibit adverse changes in the spatial and functional structure of functional urban areas.

\section{Materials and Methods}

The analytical process was carried out in two main stages to:
1. determine the degree of convergence between the occurrence and the quality of $\mathrm{Gl}$ and the inhabitants' standards of living, in particular in the residential estates of the city of Olsztyn;

2. determine the impact of Gl location within the functional and spatial structure of the city on urban development.

In order to determine the degree of convergence between the occurrence and the quality of the $\mathrm{Gl}$ and the inhabitants' standards of living, in particular in the residential estates of the city of Olsztyn, results of an analysis of the so-called indicator of natural attractiveness of the spatial units under study were collated with the results of the survey of inhabitants' opinions on the quality of life of the city population.

The indicator of natural attractiveness of spatial units comprises two aspects (the so-called partial indicators):

A. Natural attractiveness in terms of access to the resources of surface waters, determined by the following research characteristics:

- the length of the shoreline of lakes situated within particular residential estates, including the lakes whose shoreline is at the same time a boundary of a particular unit (on the length of contact between these objects);

- the length of watercourses (rivers) flowing through the area of a particular residential estate, or being their boundary (on the length of contact between these objects).

B. Natural attractiveness in terms of access to the resources of the municipal system of green areas, determined by the following research characteristics:

- the surface area of forests per 1 inhabitant of a particular residential estate;

- the surface area of cultivated and uncontrolled greenery per 1 inhabitant of a particular spatial unit (the areas of cultivated and uncontrolled greenery include the areas of recreational and leisure parks, lawns, residential estate greenery areas, and roadside greenery, 
as well as the areas of meadows, field cropland, non-urbanised parts of airport areas, and other areas covered with grasses and shrub vegetation).

- the percentage of the area of family allotment gardens in the total area of particular residential estates;

- the percentage of the area of house gardens among single-family houses in the total area of particular residential estates.

The above characteristics which quantitatively express the degree of Gl occurrence in the functional and spatial structure of the city were subjected to the standardisation process which involves the standardisation of values of particular indicators using descriptive statistics: an arithmetic mean and the standard deviation, using formula 1 :

$$
Z_{i j}=\frac{x_{i j}-\bar{x}_{j}}{S\left(x_{j}\right)}
$$

where:

$z_{i j}$ - standardised value of the i-th indicator within a particular spatial unit

$x_{i j}$ - value of the i-th indicator within a particular spatial unit

$\bar{x}_{j}$ - arithmetic mean of the indicator value in all spatial units

$S\left(x_{j}\right)$ - standard deviation from the indicator value in all spatial units.

The next step in the stage of determining partial indices of natural attractiveness of residential estates was to add up the above standardised quantitative indices. As regards the determination of the level of attractiveness of the units under study in terms of access to the resources of the municipal system of green areas, the so-called correction indicator was used, which took into account the state of greenery occurring in the units under study, with account taken of its quality and maintenance level. The correction indicator was determined based on the results of the survey of public opinion, obtained from KF Research (2016). According to the above, the indicator of natural attractiveness of spatial units was determined based on the following formula (2):

$$
v_{j}=\sum_{i=1}^{n} z_{i j} * W
$$

where:

$v_{j}$ - value of the natural environment within a particular spatial unit

$z_{i j}$ - standardised value of the i-th indicator within a particular spatial unit

$W$ - correction indicator in terms of the quality and the greenery maintenance level in a particular spatial unit.

The overall indicator of natural attractiveness of the units under study was determined by adding up the standardised and adjusted partial indices.

The first stage of the analytical process was summarised by collating the results of an analysis of the so-called overall indicator of natural attractiveness of particular units under study with the results of the survey of public opinion on the standard of living of the population of Olsztyn in the city residential estates (KF Research 2016).

The first stage of the analytical process was implemented based on the data resulting from spatial analyses carried out using the ArcGIS 10.4 software. The basic source of information was the Topographic Object Database BDOT10k made available by the Provincial Centre for Land Surveying and Cartographic Documentation in Olsztyn. The obtained data were additionally updated by making a detailed site inventory. Results of the survey of public opinion in both the qualitative state of greenery and the standard of living of Olsztyn inhabitants were taken from KF Research (2016).

In order to indicate the impact of the location of $\mathrm{Gl}$ within the functional and spatial structure of the city on its development, and the intensification of the 'urban sprawl' phenomenon (2nd stage), the distribution of builtup areas, i.e. residential areas and recreational and leisure areas situated within the cadastral districts of the municipalities forming the Municipal Functional Area of Olsztyn, 
was analysed. In addition, the rate of changes to the population density as well as migration processes taking place within the municipalities adjacent to the main city of WarmińskoMazurskie Province in the years 2007-2016 were investigated. The results of the above analyses were collated with the current functional and spatial structure of the city, which enabled the demonstration of the impact of the location of $\mathrm{Gl}$ on shaping of the urban fabric of Olsztyn as well as structural and spatial transformations occurring in suburban areas. This stage of the analytical process was implemented using the data originating from compilations of the lists of areas kept by the County Centre for Land Surveying and Cartographic Documentation as well as statistical data made available by the Central Statistical Office.

Additionally, an analysis of the case study was carried out in order to illustrate the impact of the $\mathrm{Gl}$ on spatial development of the city. An area located in the south-eastern part of Olsztyn, in the Pieczewo residential estate, one of the three so-called 'dormitory suburbs', was selected to provide an example. This case study was carried out based on planning information available on the portal of the Municipal System of Spatial Information for the City of Olsztyn (https://msipmo.olsztyn. eu). Results of the study are presented using thematic maps. The basis for the graphical interpretation of analysis results was the map of the administrative division of the city into auxiliary units (residential estates), made available by the City Council of Olsztyn, and prepared on the basis of the description of the course of their boundaries, included in Annex 6 to the Statute of the City of Olsztyn. A map of the province divided into basic units, i.e. municipalities, obtained from the National Register of Boundaries made available by the Main Centre for Land Surveying and Cartographic Documentation, was used as well.

\section{Description of the object under study}

\section{Natural values of the city of Olsztyn}

Olsztyn is a city of high environmental value, referred to as the "Garden City", situated in an area called "the Green Lungs of Poland" (Fig. 1).

The high percentage of the Gl components in the city is confirmed by the internal structure in terms of land use (Fig. 2) in 2016. Undeveloped land measures an above-average area of over $50 \%$ of the city area.

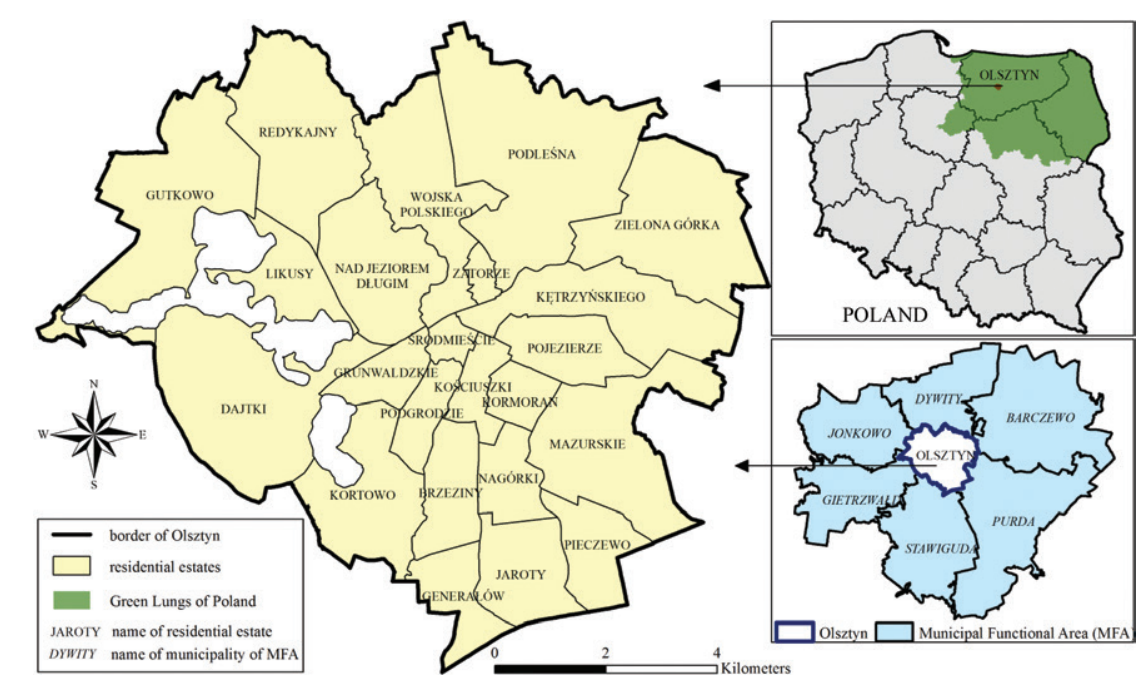

Figure 1. The area under study 

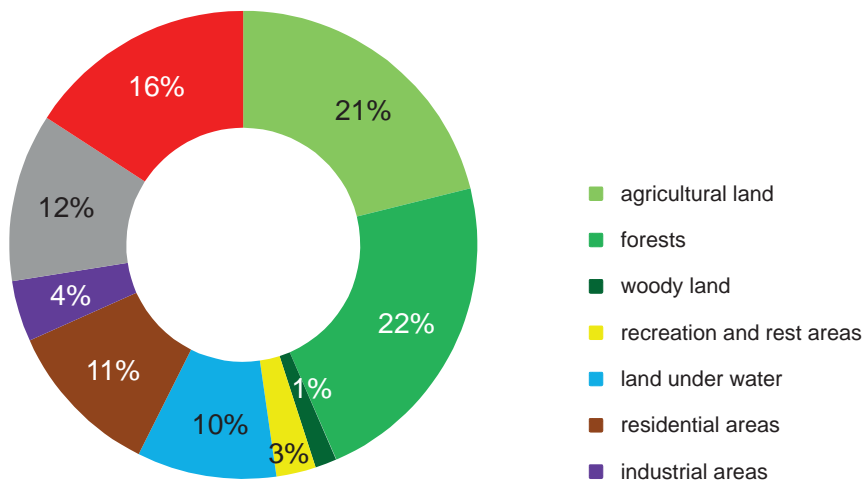

Figure 2. The structure of land use in Olsztyn

Source: Own elaboration based on the Land Inventory kept by the Provincial Centre for Land Surveying and Cartographic Documentation in Olsztyn.

The 'blue' component of Olsztyn's Gl comprises 11 lakes and 3 rivers within the administrative boundaries (with a total area of $850 \mathrm{ha}$ ), which are an extremely valuable element of the landscape, and a natural as well as a tourist and recreational asset. The main element of the 'green' component is the City Forest complex. Along with agricultural land, other forests, wooded land, bush land and allotment gardens, these areas cover approx. $45 \%$ of the city area (over $4000 \mathrm{ha}$ ) and, including waters, approx. 55\%. The spatial distribution of $\mathrm{Gl}$ elements is presented in Figure 3.

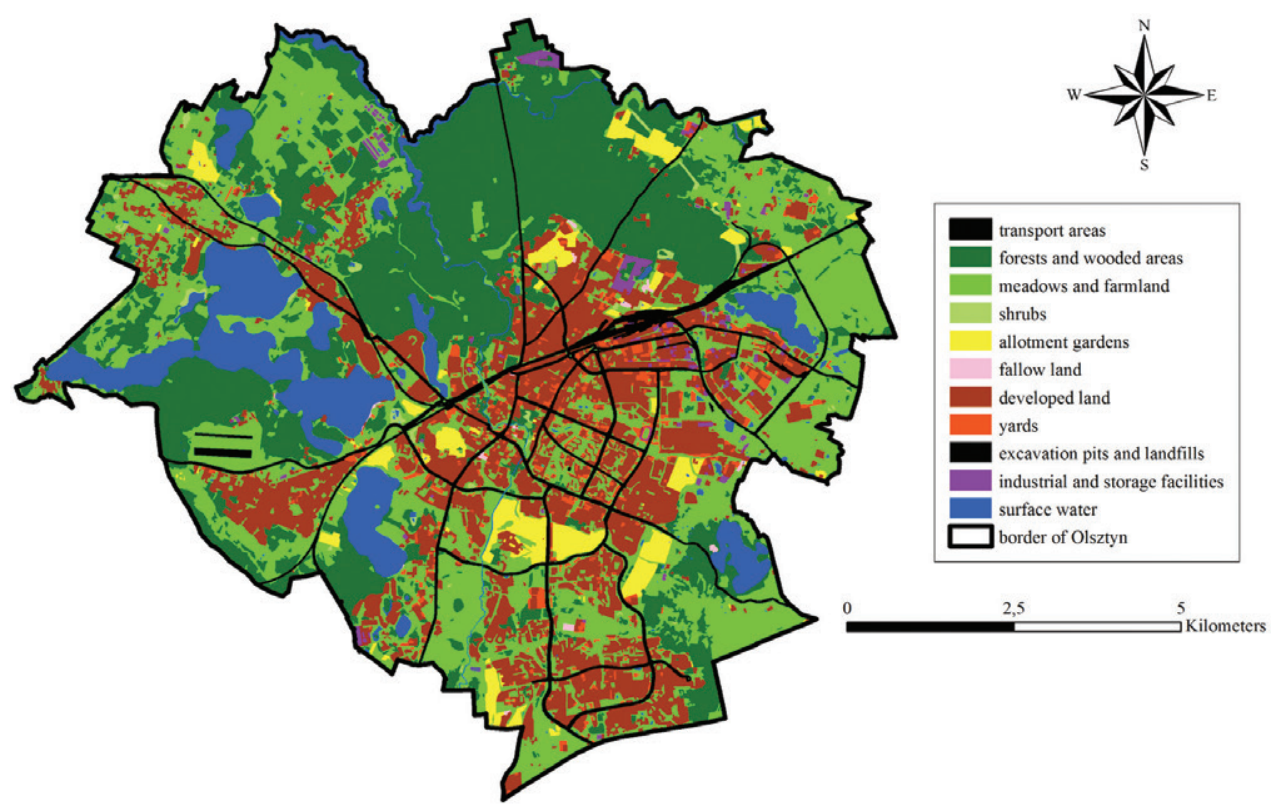

Figure 3. The spatial distribution of the structure of land use in Olsztyn

Source: own elaboration based on data of the Provincial Centre for Land Surveying and Cartographic Documentation. 
In the city, the number and surface of cultivated greenery areas, particularly walking and recreational parks which are subject to continuous renewal, have also been steadily increasing. In addition to the existing parks, the establishment of 10 new ones with an area of 189.7 ha is planned (Olsztyn City Council 2013). An adverse trend of recent years has been the noticeable reduction in the area of residential estate greenery and lawns, which results from the construction of car parks and the concentration of buildings; however, the city carries out compensatory plantings in order to compensate for these losses. Within the urban space of Olsztyn, numerous legally protected areas are found, namely, nature reserves and protected landscape areas (measuring over 10\% of the city area) as well as natural monuments.

\section{System of green areas in Olsztyn}

The city of Olsztyn is characterised by an extensive structure of use resulting from the occurrence of a large area of open areas (see Fig. 2). The green component of the Gl system in Olsztyn is comprised of the following:

- the Municipal Forest, situated in the northern part of the city, occupies an area of $1,393.47 \mathrm{ha}$, of which the area of forests is 1,319.06 ha. This is a refuge for wild animals and numerous plant species preserved in their original form in protected reserves. The forest stand of Olsztyn has the appropriate values to satisfy the criteria set for recreational forests;

- urban parks - 13 parks with an area of $84.43 \mathrm{ha}$, which are the publicly available, organised urban green space serving leisure and recreational functions. The main city parks include Central Park, Castle Grounds Park, Kusociński Park, Jakubowo Park, Black Lake Park, Wojska Polskiego Street Park, and Kortowo Park;

- family allotment gardens - 33 allotment garden complexes with an area of approx. 230 ha (Olsztyn is a national leader in terms of the area of allotments situated in a city), which, along with those used illegally, measure over $3 \%$ of the city area. Allotment garden complexes are situated between built-up areas and interfere with spatial development of the city. They provide the default direction of the development of land improvements, and are large enclaves of green areas among buildings, which make them naturally valuable (Olsztyn City Council 2013);

- orchards - orchard areas are still to be found within the administrative boundaries of the city (39 ha);

- house gardens with a total area of approx. 630 ha, which are classified as residential areas. They accompany residential buildings, particularly among single-family houses, are their immediate surroundings, and serve both aesthetic and recreational role. Moreover, they are of great significance due to their agrobiodiversity, as they are characterised by the occurrence of numerous species and varieties of ornamental plants;

- open areas comprising grassland and wasteland found within the administrative boundaries of the city (approx. 806 ha);

- areas of residential estate greenery among multi-family residential buildings and roadside greenery.

\section{Quality of life in Olsztyn}

The collective quality of life comprises all generalisations of individual qualities of life, resulting inter alia from surveys (Borys 2008). In 2016, a survey of the inhabitants' opinions on the quality of life in a city was carried out in Olsztyn. The assessment of the quality of life was individually conducted by individual inhabitants, and then aggregated in order to determine the standard of living in particular residential estates of the city. The results were presented in a study entitled "A survey of Olsztyn inhabitants' opinions, their problems and the vision of the city (KF Research 2016). The report emphasizes that the greatest advantage of living in Olsztyn is the location of the city and the Gl compo- 
nents which provide enormous possibilities as regards leisure and recreation and are so important to the inhabitants' quality of life. An undoubted advantage of living in Olsztyn is the possibility for various contacts with the nature. The advantages/pros of living in Olsztyn mentioned by the inhabitants are as follows: lakes - 45\%; green areas/parks $20 \%$; forests - 20\%; landscape/nature - 20\%; clean air/environmental state - 9\%; it should be also noted that the inhabitants want this green infrastructure to continue to develop. The report results indicate that in the inhabitants' opinions, the quality of life has been steadily increasing. This is a long-term trend resulting from numerous actions taken by municipal authorities to enhance the quality of open areas.

\section{Results}

Natural attractiveness of the units under study in terms of their richness in the 'blue' component of $\mathrm{Gl}$ is determined by the access to the shoreline of lakes and by the length of watercourses (rivers) flowing through their area. Results of analyses of the above research characteristics are presented in Figure 4 . The above diagram indicates that the residential estates with access to the longest shoreline of lakes are Gutkowo, Likusy, and Dajtki. These are spatial units located in the north-western part of Olsztyn, situated at the largest water body of the city, i.e. Lake Ukiel. In addition, other natural water bodies are found within these residential estates: Lake Redykajny and Lake Tyrsko in Gutkowo, Lake Czarne in Likusy, and Lake Kortowskie in Dajtki. In turn, the units under study situated in the central and southern part of Olsztyn are characterised by a complete lack of access to the shoreline of water bodies. Having interpreted the results of an analysis of the length of watercourses (rivers) flowing through the area of particular residential estates, it can be concluded that the spatial units situated in the northern part of the city, i.e. the residential estates Podleśna, Wojska Polskiego, Nad Jeziorem Długim, and Redykajny, are characterised by the longest sections of river beds.

The main river axis of Olsztyn, i.e. the Łyna River, and its right tributary, the Wadag River, flow through their area. In turn, in the residen-

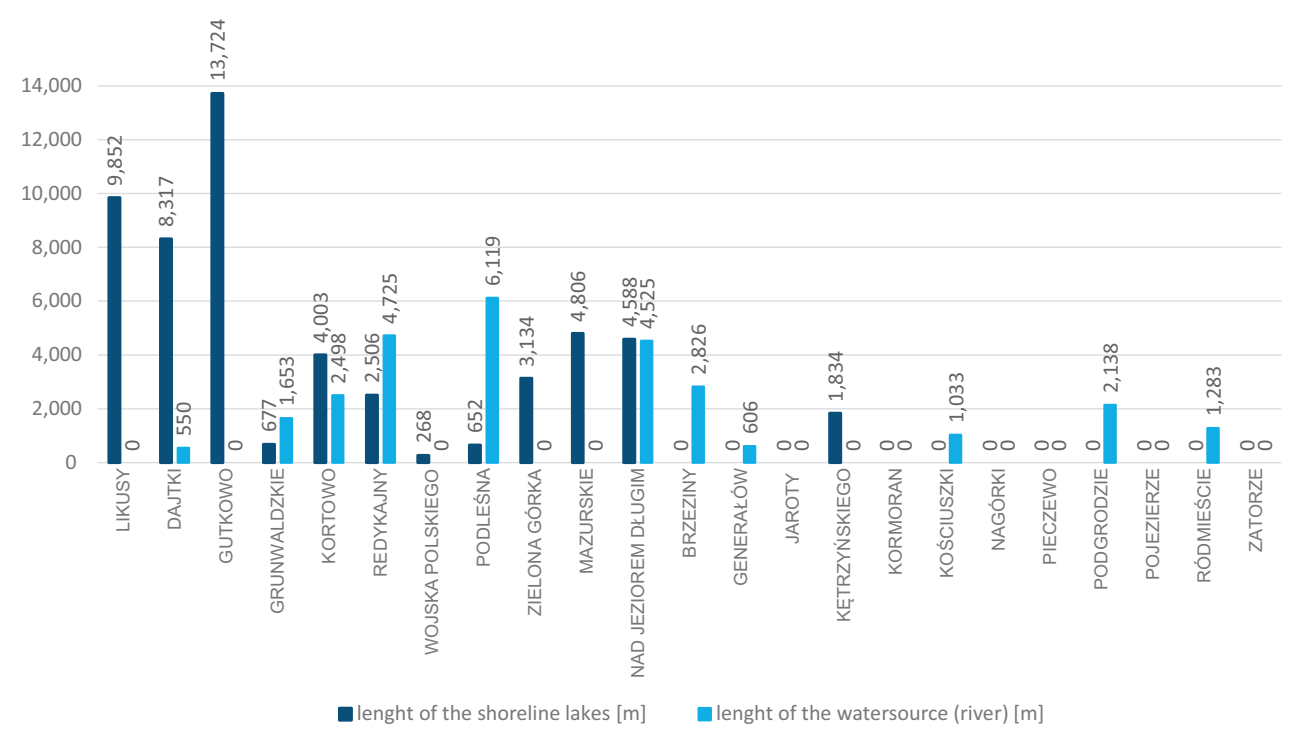

Figure 4. The length of the shoreline of lakes and the length of the watercourse in particular residential estates of the city of Olsztyn 
tial estates located in the eastern part of the city, no occurrence of natural watercourses (rivers) was found. The above diagram also reveals that within the structure of the city, with account taken of its division into auxiliary units, there are residential estates characterised by a complete lack of access to the 'blue' component of the Gl. These units include: Jaroty, Nagórki, and Pieczewo i.e. three largest 'dormitory suburbs' of Olsztyn, and Kormoran, Pojezierze, and Zatorze i.e. residential estates located in the central part of the city, characterised by dense residential and service development.

A synthetic approach to the abovedescribed conditions determining the natural attractiveness of the units under study in terms of their access to the resources of surface waters (lakes and rivers) is presented in Figure 5a. The residential estates located in the northern and western parts of Olsztyn are characterised by the highest level of attractiveness in this regard. On the other hand, the spatial units forming a belt starting in the city centre, directed towards its southern boundary, are areas which are naturally unattractive due to the lack of any natural resources of surface waters. These are heavily urbanised areas inhabited by approx. 53\% of the population of Olsztyn.

Natural attractiveness of the units under study in terms of their richness in the 'green' component of $\mathrm{Gl}$ is determined by the degree of occurrence of the forms of use making up the municipal system of green areas, i.e. forests and wooded land, areas of cultivated and uncontrolled greenery, family allotment gardens and house gardens among single-family houses. A synthetic approach to the above conditions determining the natural attractiveness of the units under study in terms of their access to the resources of the municipal system of green areas, with account taken of the state of greenery maintenance, is presented in Figure 5b. The residential estates located in the northern part of Olsztyn are characterised by the greatest natural attractiveness in this regard. A significant area of these spatial units is occupied by the dense com- plex of the Municipal Forest. In addition, the system of green areas in this part of the city also comprises family allotment gardens (e.g. in the residential estates of Podleśna, Gutkowo, and Dajtki) as well as numerous house gardens among single-family houses (the residential estates of Gutkowo, Dajtki, Redykajny, Likusy, Podleśna, and Nad Jeziorem Długim). Moreover, various forms of cultivated greenery designed for leisure and recreation are found there (inter alia Jakubowo Park, Black Lake Park, Wojska Polskiego Street Park, lawns, and squares). Apart from the residential estates situated in the north, the residential estates of Brzeziny and Mazurskie are characterised by a relatively high indicator of attractiveness in this regard. Their system of green areas primarily comprises the large areas of allotment gardens and numerous house gardens among single-family houses as well as the areas of uncontrolled greenery at the Łyna River (Brzeziny residential estate) and at Lake Skanda (Mazurskie residential estate). In turn, the spatial units with the lowest level of natural attractiveness in terms of richness in the 'green' component of Gl are the residential estates located in the central part of the city, i.e. Pojezierze, Kormoran, Podgrodzie, Śródmieście, Kościuszki, Zatorze and Kętrzyńskiego, and the residential estates located near the southern boundary of Olsztyn, i.e. Pieczewo and Jaroty. These units under study are heavily urbanised, and have predominant housing developments (e.g. Jaroty, Pieczewo, Pojezierze, Kormoran, and Podgrodzie), service developments (e.g. Śródmieście, Kościuszki), and industrial developments (e.g. Kętrzyńskiego residential estate). Their system of green areas primarily comprises residential estate greenery and roadside greenery as well as several small municipal recreational and leisure parks (inter alia Castle Grounds Park, Central Park, and Kusociński Park).

The synthetic indicator of natural attractiveness of spatial units in terms of their richness in Gl is presented in Figure 5c. Having analysed the results of conducted studies, it can be noted that in terms of the natural 

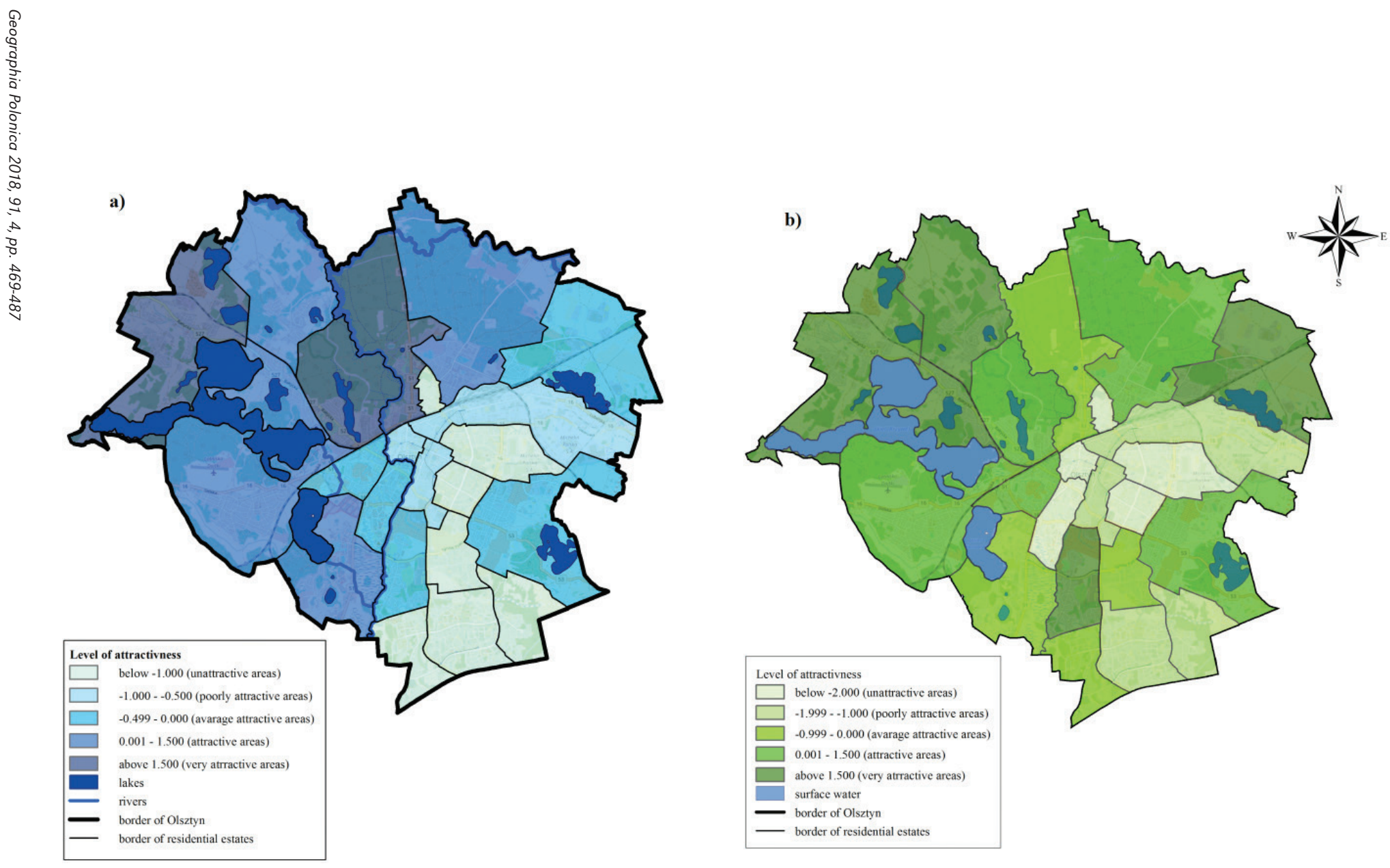

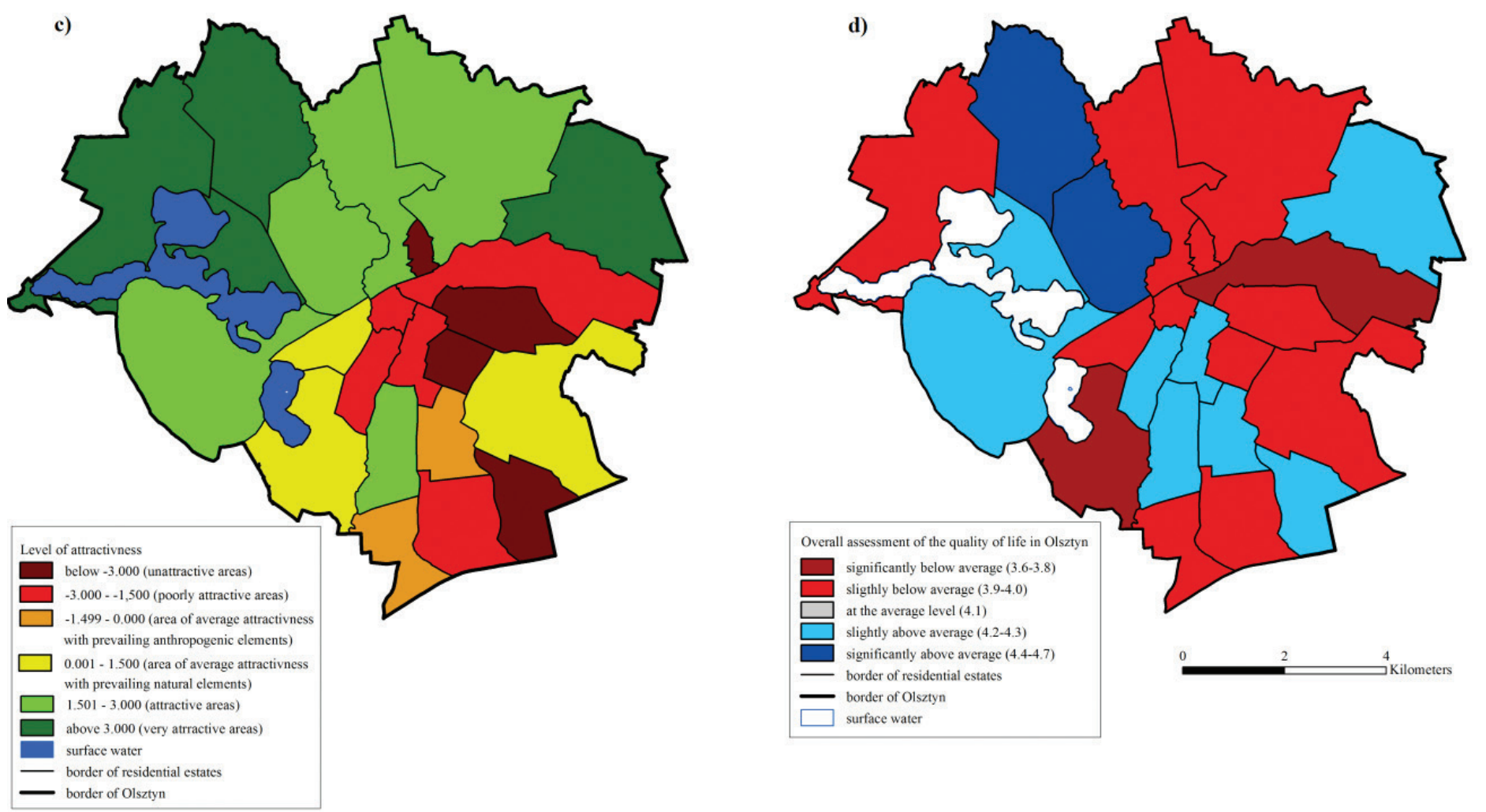

Figure 5. Natural attractiveness of the residential estates of the city of Olsztyn in terms of: a) access to the resources of surface waters, b) access to the resources of municipal system of green areas, with account taken of this quality; c) natural attractiveness of residential estates of the city of Olsztyn; d) the quality of life in Olsztyn in relation to residential estates

Source: a, b, c - own elaboration, d - own elaboration based on KF Research (2016) "A survey of Olsztyn inhabitants' opinions, their problems, and the vision of the city. Report of the survey. 2016, Olsztyn. 
attractiveness, the area of the city is divided into two basic parts: the northern part, with very considerable resources of $\mathrm{Gl}$, and the southern part, with not very attractive natural conditions, being more urbanised. As regards the functional and spatial structure of the city, it should be noted that the line of this division is determined by the railway line. The development of the city progressed primarily towards the south, and the only exception in this regard is Zatorze residential estate in which the intensification of housing developments occurred as a result of the constructed railway line. In both separated parts, however, small enclaves, i.e. areas with a completely different nature, are found. In the northern, the so-called natural part, such an enclave with the characteristics of an urbanised area is the Zatorze residential estate. On the other hand, in the southern, the so-called urbanised part, the exception is the Brzeziny residential estate, which is characterised by a relatively high indicator of natural attractiveness. At present, however, the spatial policy of the city envisages the initiation of actions aimed at the intensification of urbanisation of the area concerned, making use of the 'open' areas of uncontrolled greenery to this end.
Results of the global assessment of the quality of life in Olsztyn, presented in the publication "A survey of Olsztyn inhabitants' opinions, their problems, and the vision of the city. Report of the survey" (KF Research 2016), are presented in Figure $5 d$. The results presented in the map are a graphic interpretation of the results of the survey of opinions of Olsztyn inhabitants as regards the quality of life in relation to various determinants, including natural ones.

In order to determine the impact of the location of $\mathrm{Gl}$ within the functional and spatial structure of the city of Olsztyn on its development, and the intensification of the 'urban sprawl' phenomenon (2nd stage), the distribution of built-up areas, including residential areas and recreational and leisure areas situated within particular cadastral districts of the municipalities forming the Municipal Functional Area of Olsztyn, was analysed. The analysis results are presented in Figure 6. An analysis of the spatial distribution of built-up areas leads to the conclusion that the majority of densely developed areas in the city of Olsztyn are situated along the southern fragment of the railway line, i.e. in residential estates with low levels of nat-

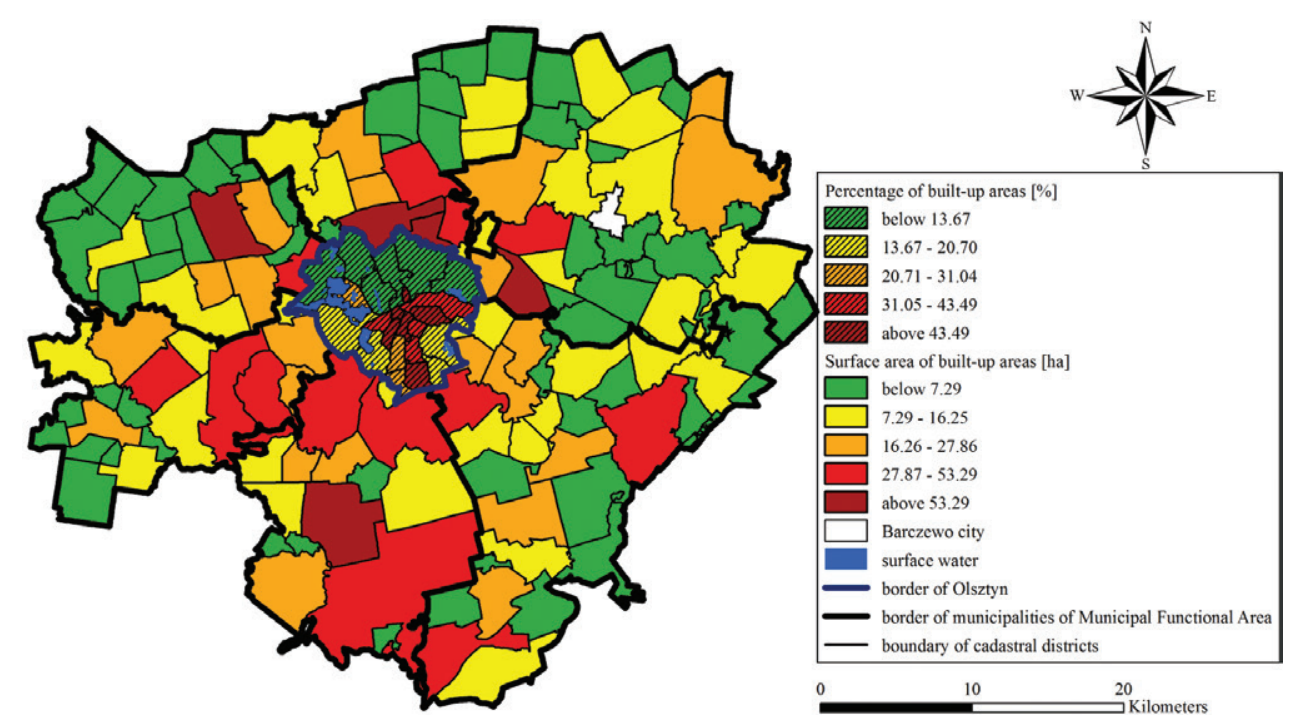

Figure 6. Built-up areas in the Municipal Functional Area of Olsztyn 
ural attractiveness. Therefore, the capacity of these areas for residential and service development is continuously decreasing. In turn, in the northern part of the city, which is rich in natural resources, the intensification of urban development is inhibited, primarily due to the presence of the dense Municipal Forest complex which poses a natural barrier to urban development. Both discussed factors could have contributed to an increase in the area of developed land within the cadastral boundaries of the municipalities that surround the city on the north and south side. Developed land 'sprawls' mainly in the southern direction towards the municipality of Stawiguda which is a natural continuation of the most densely developed areas. Numerous new areas designated for investment projects, particularly residential ones, are also implemented in the municipalities situated to the north, i.e. the municipality of Dywity, outside the Municipal Forest boundaries (where urban development has the characteristic features of leap-frog urban sprawl).

The consequences of suburbanization are visible in the movement of the urban population to the rural municipalities that surround the city. In order to investigate the level of internal intra-municipality migration to be registered for permanent residence in the direction from a city to a village within the area under study, the lines of the trend indicating the number of people who officially registered the change of their address and moved to rural areas (blue colour) were collated with the number of officially registered people from towns in the sub-Olsztyn municipalities (red colour). The analysis results are presented in Figure 7. It can be observed in the diagram that both lines of the trend maintain convergence and are very close to each other, which may indicate the fact that the vast majority of the people who decide to officially register a change of their address and move from Olsztyn go to the municipalities surrounding it. The magnitude of these internal migrations in particular years is primarily determined by the number of housing resources put-into use.

Suburbanization and the movement of people to suburban areas lead to changes in the distribution of the population both within the city and in the adjacent municipalities. In order to investigate the magnitude of these effects in the area under study, changes to the population density in the years 2007-2016 were analysed. The results are presented in Figure 8. In all municipalities surrounding Olsztyn, a significant increase (by an average of approx. $23 \%$ ) in the population density was noted. In turn, in the city itself, the population density decreased by $1.5 \%$. The great-

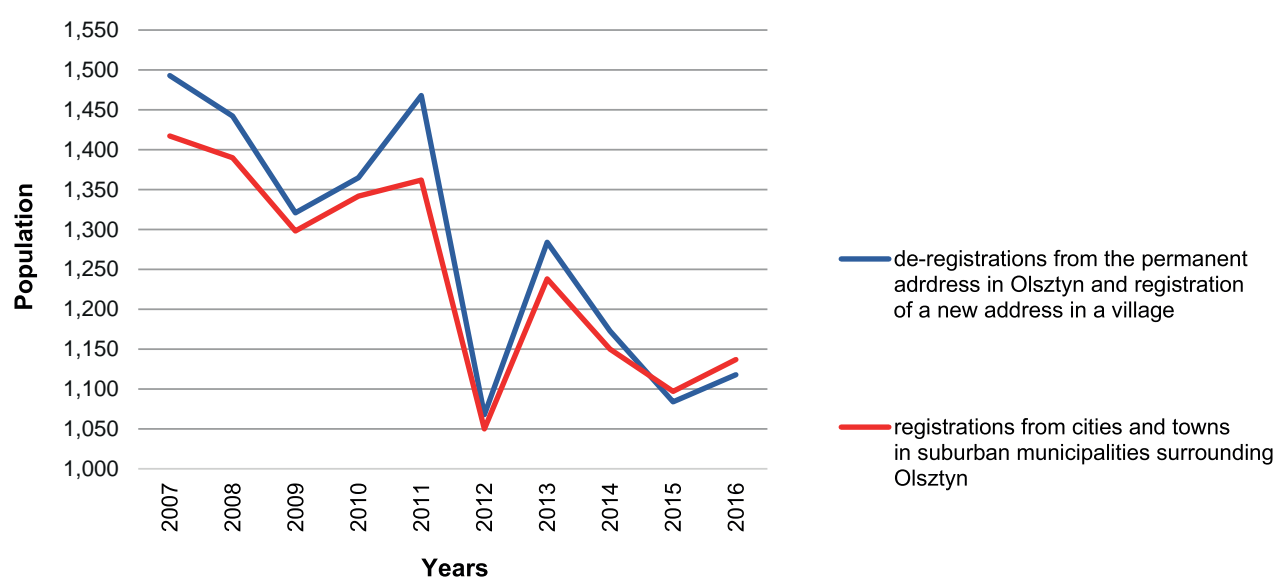

Figure 7. Internal migrations to be registered for permanent residence, communal, according to the direction (village, city) 


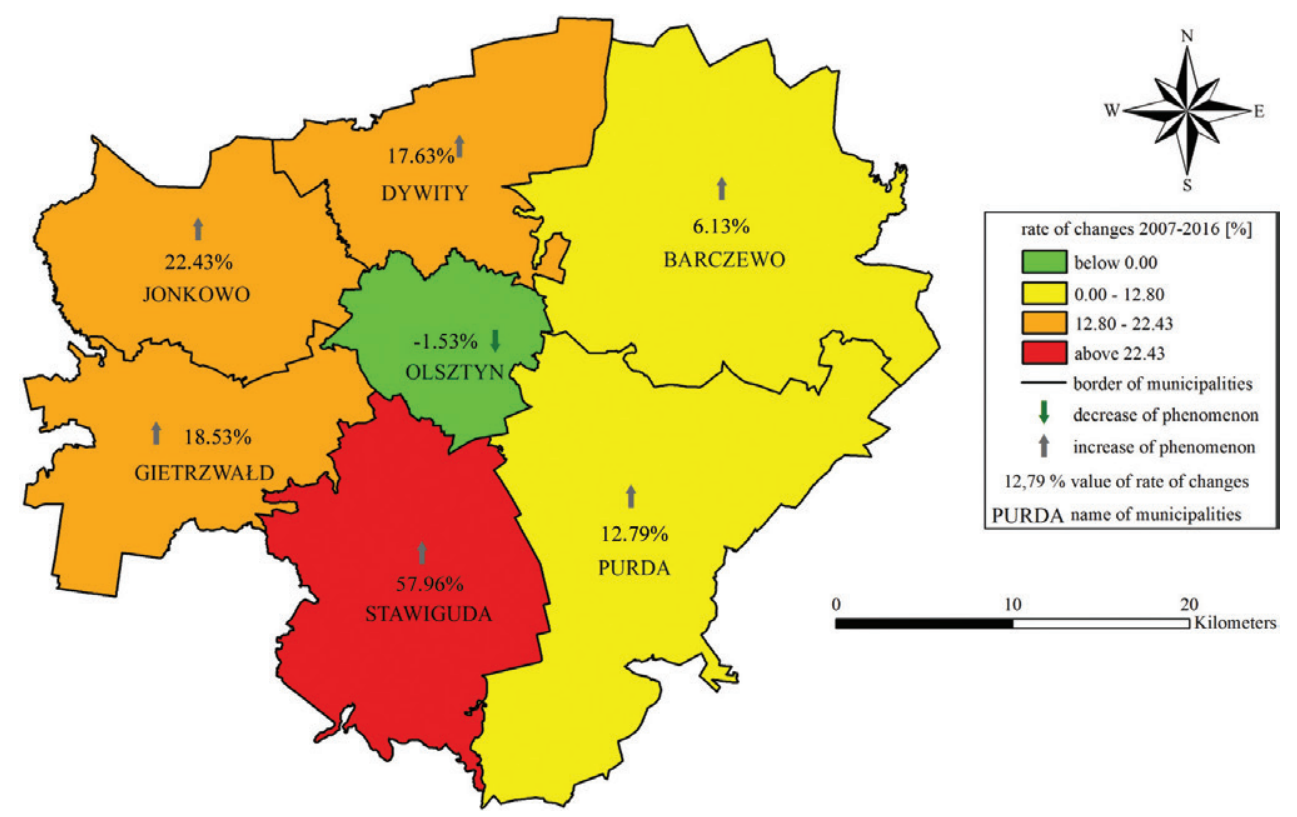

Figure 8 . The rate of changes to the population density in the city of Olsztyn and in the suburban municipalities in the years 2007-2016

est increase (approx. 58\%) in the population density during the period under analysis was noted in the municipality of Stawiguda. In the municipalities of Gietrzwałd, Jonkowo, and Dywity, an increase in the number of people per $1 \mathrm{~km}^{2}$ of the area was noted as well. This increase was at a level of approx. 20\%. The results of these studies are confirmed by the basic directions of the progressive phenomenon of 'urban sprawl'.

In order to stop or minimise this process, local authorities take planning measures aimed at the partial development of the open areas. These measures involve designating areas of uncontrolled greenery, located in the southern part of the city, to be built-up with residential and service buildings. A typical example is the area of the former military training ground situated in the residential estate of Pieczewo, which is currently unused and is a rich resource of $\mathrm{Gl}$ in this part of the city (Fig. 9).

The area is covered with low and high grasses (numerous trees and bushes). This is one of the main resources of $\mathrm{Gl}$ and a place for walks for the inhabitants of the three 'dormitory suburbs' of Olsztyn, i.e. Jaroty, Pieczewo, and Nagórki.

For the area concerned, local authorities have developed a local area development plan for the residential estate of Pieczewo, most of which has been designated for the construction of residential and service buildings.

The consequence of the urbanisation of this area will be another loss of green areas in the southern part of the city. With progressive actions of a similar nature, focusing on the south of the course of the railway line, it is highly probable that the system of Gl resources in this part of the city will be significantly depleted. The effect of this situation may be a progressive increase in the degree of inhabitants' dissatisfaction with the quality of life in this area of Olsztyn.

\section{Discussion}

When the results of the synthetic indicator of natural attractiveness of particular resi- 

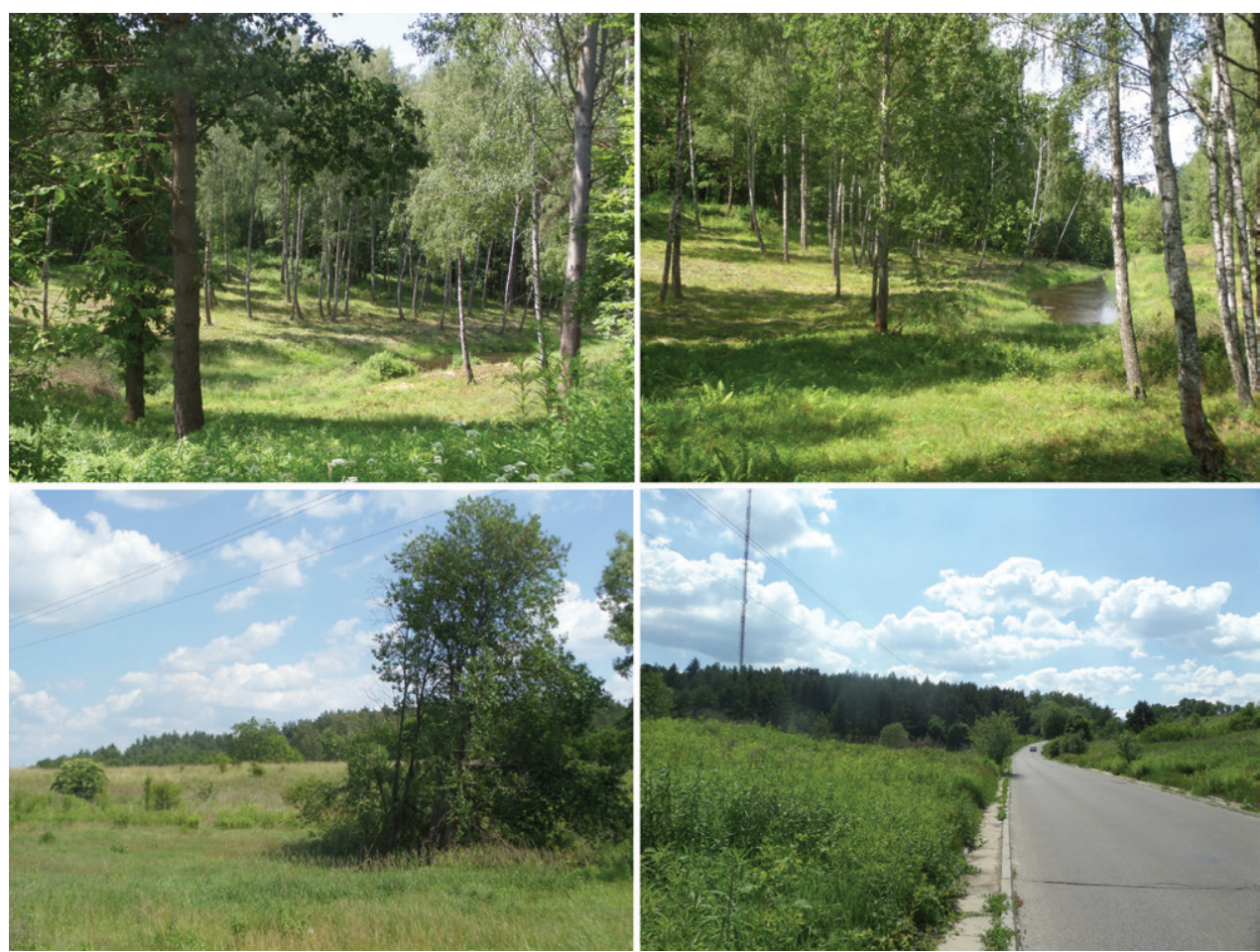

Figure 9. Photographic evidence of the current state of open areas in the Pieczewo residential estate

dential estates are collated with the results of the global assessment of the quality of life in Olsztyn, it could appear that the access to $\mathrm{Gl}$ resources is significantly linked with the inhabitants' standard of living. The northern part of the city of Olsztyn is characterised by a high level of natural attractiveness, and the people living there enjoy a high quality of life, while the southern part of the city is characterised by poor access to the Gl resources and, at the same time, by a lower standard of living of its inhabitants.

In the area situated to the north of the course of the main railway line, where a high level of natural attractiveness was diagnosed, opinions of inhabitants of residential estates of Dajtki, Nad Jeziorem Długim, Likusy, Redykajny, and Zielona Górka described the quality of life as being at a level above average. In the urbanised enclave situated in this natural part of the city, namely, the residential estate of Zatorze, the standard of inhab- itants' living was described as slightly below average. Having analysed the situation in the southern part of the city in this regard, it can be noted that in the units under study in which the level of natural attractiveness was described to be at a low level (i.e. the residential estates of Kętrzyńskiego, Śródmieście, Pojezierze, Kormoran, Generałów and Jaroty), the quality of life was, in the inhabitants' opinion, described as being at a level below or significantly below the average. In the natural enclave situated in this more urbanised part of the city, i.e. the residential estate of Brzeziny, the standard of inhabitants' living was described as slightly above average. The above results suggest that the access to $\mathrm{Gl}$ resources could be one of the factors that influence the quality of life in different parts of the city, next to economic, social, demographic, legal and spatial policy factors.

Due to the occurrence of rich GI resources in the northern part of the city, a vast majority 
of investment processes are still implemented in the areas located towards the south, which increases the depletion of the already poorly developed Green Infrastructure. The entire 'burden' of urbanisation is focused on this part of the city. Where the capacity of these areas for 'accepting' further buildings is continuously decreasing, the buildings start to 'spread out' beyond its boundaries, thus intensifying the adverse phenomenon of 'urban sprawl'.

To summarise the issue of the impact of the location of $\mathrm{GI}$ within the functional and spatial structure of the city of Olsztyn on its development, and the intensification of the phenomenon of 'urban sprawl', it should be concluded that the main city of the province of Warmia-Mazury is an example of how a richness in natural resources contributes to an increase in the quality of inhabitants' lives although it also forms a spatial barrier to the development of the city. This is indeed due to the occurrence of unique resources of $\mathrm{Gl}$ that the urbanisation processes in the northern part of the city are poorly intensified. The entire 'burden' of urbanisation is therefore focused on the southern part of the city. Due to the reduction in constructional capacity of these areas caused by the occurrence of numerous environmental components, buildings start to 'spread out' beyond the city boundaries, thus intensifying the adverse phenomenon of 'urban sprawl'.

However, few authors report that GI may also have an adverse effect on spatial development of a city and its structures (Miller, 2016; Burton et al., 2003; Szulczewska \& Kaliszuk, 2005; Baycan-Levent \& Nijkamp, 2009). The contemporary approach to city development emphasises the need for the concentration of buildings within the administrative boundaries of cities - the concept of a 'compact city' with high building density as a model of future cities in Europe. This is aimed at reducing chaotic and costly suburbanisation, resulting in the degradation of the $\mathrm{Gl}$ in rural areas (Li et al. 2016). However, this appears to be in conflict with the development of $\mathrm{Gl}$ in cities. Cities with a high index of $\mathrm{Gl}$ are characterised by an extensive structure of use, which translates into the lack of space designated for residential development projects. This is why buildings are moved to suburban areas: while providing city dwellers with numerous open areas, we thus reduce the space designated for investment projects.

\section{Conclusion}

The integrated Green Infrastructure system is one of major components that shape the functional and spatial structure of cities. It is a basic component of the urban fabric, adding value to the space. The GI resources in the architectural composition of cities are a good that is commonly socially desirable. The current demands of society as regards the residential environment increasingly refer to the natural determinants of the urban fabric. Access to the system of Gl resources is becoming a significant factor determining the quality of urban dwellers' lives. The system of green areas (including inter alia the areas of uncontrolled greenery) is the socalled 'urban open spaces'. Such areas very frequently are under pressure of progressive urbanisation processes and some fragments of the areas of the system of $\mathrm{Gl}$ resources are 'consumed' for the benefit of new buildings, usually residential and service ones. The consequences of these actions include a disturbance to the system of urban green areas and even the interruption of its functional continuity. This translates into socially negative valuation of the space, followed by a decrease in the quality of inhabitants' lives.

In some cases, including in the city of Olsztyn, green areas (in particular dense municipal forest complexes), are regarded as unique public goods where investment projects with a strictly urban character are prohibited in an attempt to improve the quality of life. In this approach, Gl resources can pose a barrier to the spatial development of the city, which contributes to urban sprawl. The result is a paradox of sorts: green areas improve living standards, but also hamper 
urban development, which can lead to migration to suburban areas (with a high quality of the natural environment) and damage to the natural resources around the city. The city of Olsztyn is highly deficient in residential areas located within the administrative boundaries. New residential complexes are developed as infill sites in waterlogged areas (near the Łyna River) and defunct industrial and business sites (demolished buildings). The above influences the decisions made by the local authorities who make attempts to partially manage undeveloped land, including land of the lowest quality.

Conclusions from these studies may provide preliminary guidelines for town planners and developers in the field of the favourable selection of new housing investments, main-

\section{References}

Badiu D. L., Iojă C. I., Pătroescu M., Breuste J., Artmann M., Nită M.R., Gradinaru S.R., Hossu C.A., Onose D.A., 2016. Is urban green space per capita a valuable target to achieve cities' sustainability goals? Romania as a case study. Ecological Indicators, vol. 70, pp. 53-66.

Baycan-LeVent T., NiJkamp P., 2009. Planning and management of urban greenspaces in Europe: comparative analysis. Journal of Urban Planning and Development, vol. 135, pp. 1-12.

BŁaszczyk M., Kosmala M., 2008. Społeczne znaczenie zieleni ulicznej i jej wpływ na ocenę możliwości użytkowania przestrzeni. Nauka Przyroda Technologie, vol. 2, no. 4, pp. 1-10.

BORYS T., 2008. Propozycja siedmiu typologii jakości życia. Gospodarka a Środowisko, vol. 22, pp.125-134.

BÖHM A., 2007. Zasady i pokusy. Czasopismo Techniczne Architektura, vol. 104, pp. 10-16.

Burton E., Jenks M., Williams K. (eds.) 2003. The compact city: A sustainable urban form? Oxford, UK: Routledge.

Camps-Calvet M., Langemeyer J., Calvet-Mir L., Gómez-Baggethun E., 2016. Ecosystem services provided by urban gardens in Barcelona, Spain: Insights for policy and planning. Environmental Science \& Policy, vol. 62, pp. 14-23. taining a high quality of so-called 'natural surroundings', and ensuring a high level of residents' life. At the same time the results show how a housing environment which is attractive in terms of nature, affects the opinions expressed by residents, thereby showing their preferences in the field of $\mathrm{Gl}$ in the place of residence. Therefore, Gl should be distributed evenly throughout the city to enhance its functional and spatial structure, and to improve the residents' quality of life. Similar conclusions were formulated by Degórska and Degórski (2017).

Editors' note:

Unless otherwise stated, the sources of tables and figures are the authors', on the basis of their own research.

Connop S., Vandergert P., Eisenberg B., Collier M.J., Nash C., Clough J., Newport D., 2016. Renaturing cities using a regionally-focused biodiversity-led multifunctional benefits approach to urban green infrastructure. Environmental Science \& Policy, vol. 62, pp. 99-111.

Degórska B., Degórski M. 2017. Green infrastructure as a very important quality factor in urban areas - Warsaw case study. Europa XXI, vol. 32, pp. 51-70.

de la Barrera F., Reyes-Paecke S., Harris J., BascuÑÁN D., Farías J.M., 2016. People's perception influences on the use of green spaces in socioeconomically differentiated neighborhoods. Urban Forestry \& Urban Greening, vol. 20, pp. 254-264.

Derkzen M.L., van Teeffelen A.J., Verburg P.H., 2017. Green infrastructure for urban climate adaptation: How do residents' views on climate impacts and green infrastructure shape adaptation preferences? Landscape and Urban Planning, vol. 157, pp. 106-130.

$\mathrm{EEA}, 2011$. Green infrastructure and territorial cohesion. The concept of green infrastructure and its integration into policies using monitoring systems. European Environment Agency Technical report No 18/2011, Publications Office of the European Union. 
ERNSTSON H., 2013. The social production of ecosystem services: A framework for studying environmental justice and ecological complexity in urbanized landscapes. Landscape and Urban Planning, vol. 109, pp. 7-17.

Feng Y., Burian S., Pomeroy C., 2016. Potential of green infrastructure to restore predevelopment water budget of a semi-arid urban catchment. Journal of Hydrology, vol. 542, pp. 744-755.

Garmendia E., Apostolopoulou E., Adams W.M., BormpoudAKIS D., 2016. Biodiversity and Green Infrastructure in Europe: Boundary object or ecological trap? Land Use Policy, vol. 56, pp. 315-319.

GUS, 2014. Turystyka i wypoczynek w gospodarstwach domowych w 2013 r. [Tourism and leisure in households in 2013]. Warszawa: Główny Urząd Statystyczny.

GUS, 2016. Jakość życia w Polsce: Edycja 2016 [The quality of life in Poland: Edition 2016]. Warszawa: Główny Urząd Statystyczny.

GUS, 2017. Jakość życia w Polsce: Edycja 2017 [The quality of life in Poland: Edition 2017]. Warszawa: Główny Urzad Statystyczny.

Hassan R., Scholes R., Ash N. (eds.), 2005. Ecosystems and Human Well-being: Current State and Trends. Volume 1. Millennium Ecosystem Assessment, Washington-Covelo-London: Islandpress.

Kabisch N., Strohbach M., HaAse D., KronenBERG J., 2016. Urban green space availability in European cities. Ecological Indicators, vol. 70, pp. 586-596.

KF ReseARCH, 2016. Badanie opinii mieszkańców Olsztyna ich problemów i wizji miasta. Raport $z$ badania [A survey of Olsztyn inhabitants' opinions, their problems, and the vision of the city. Report of the survey]. Olsztyn: Agencja Badawcza KF Research.

KIM H.W., PARK Y., 2016. Urban green infrastructure and local flooding: The impact of landscape patterns on peak runoff in four Texas MSAs. Applied Geography, vol. 77, pp. 72-81.

Kuo F.E., Sullivan W.C., 2001. Aggression and violence in the inner city: Effects of environment via mental fatigue. Environment and Behavior, vol. 33, no. 4. pp. 543-571.
Lanza K., Stone B., 2016. Climate adaptation in cities: What trees are suitable for urban heat management? Landscape and Urban Planning, vol. 153, pp. 74-82.

LI B., Chen D., Wu S., Zhou S., Wang T., Chen H., 2016. Spatio-temporal assessment of urbanization impacts on ecosystem services: Case study of Nanjing City, China. Ecological Indicators, vol. 71, pp. 416-427.

LIN B.S., LIN C.T., 2016. Preliminary study of the influence of the spatial arrangement of urban parks on local temperature reduction. Urban Forestry \& Urban Greening, vol. 20, pp. 348-357.

LIS A., Weber-SinIRSKA M., ZIEMIAŃSKA M. 2016. Metoda oceny i weryfikacji doboru roślin $w$ aspekcie bezpieczeństwa przestrzeni. Przestrzeń i Forma, vol. 26, pp. 213-228.

Liu W., Chen W., Feng Q., Peng C., Kang P., 2016. Cost-benefit analysis of green infrastructures on community stormwater reduction and utilization: A case of Beijing, China. Environmental Management, vol. 58, no. 6, pp. 1015-1026.

MAKSYMIUK G. 2013. Wpływ zielonej infrastruktury na wartość ekonomiczna nieruchomości. Problemy Ekologii Krajobrazu, vol. 36, pp. 145-153.

Matthews T., Lo A.Y., Byrne J.A,. 2015. Reconceptualizing green infrastructure for climate change adaptation: Barriers to adoption and drivers for uptake by spatial planners. Landscape and Urban Planning, vol. 138, pp. 155-163.

Mell I.C., Henneberry J., Hehl-Lange S., Keskin B., 2016. To green or not to green: Establishing the economic value of green infrastructure investments in The Wicker, Sheffield. Urban Forestry \& Urban Greening, vol. 18, pp. 257-267.

Michniewicz-Ankiersztajn H., 2014. Rola zieleni w kształtowaniu przestrzeni miast europejskich w kontekście jakości życia ich mieszkańców. Journal of Health Sciences, vol. 4, no. 13, pp. 130-140.

MILLER J.T., 2016. Is urban greening for everyone? Social inclusion and exclusion along the Gowanus Canal. Urban Forestry \& Urban Greening, vol. 19, pp. 285-294.

MoRAKINYO T.E., LAM Y.F., HAO S., 2016. Evaluating the role of green infrastructures on near-road pollutant dispersion and removal: Modelling and measurement. Journal of environmental management, vol. 182, pp. 595-605. 
OLSZTYN CITY COUNCIL, 2013. Studium uwarunkowań i kierunków zagospodarowania przestrzennego Olsztyna 2013 r. [A study on determinants and directions of spatial development of Olsztyn, 2013]. Resolution of the City Council No XXX$\mathrm{VII} / 660 / 13$ of 15 May 2013 on a change to the study on determinants and directions of spatial development of the City of Olsztyn - consolidated text.

Paliwoda J., Kowarik I., VON der Lippe M., 2017. Human-biodiversity interactions in urban parks: The species level matters. Landscape and Urban Planning, vol. 157, pp. 394-406.

PAPUZIŃSKI A., 2006. Świadomość ekologiczna w świetle teorii i praktyki. Problemy Ekorozwoju, vol. 1, no. 1, pp. 33-40.

Puzdrakiewicz K., 2017. Zielona infrastruktura jako wielozadaniowe narzędzie zrównoważonego rozwoju. Studia Miejskie, vol. 27, pp.155-174.

Salata K. D., Yiannakou A., 2016. Green Infrastructure and climate change adaptation. Tema. Journal of Land Use, Mobility and Environment, vol. 9, no. 1, pp. 7-24.

Sandström U.G., Angelstam P., Khakee A., 2006. Urban comprehensive planning - identifying barriers for the maintenance of functional habitat networks. Landscape and Urban Planning, vol. 75, no. 1-2, pp. 43-57.

Sang Å.O., Knez I., Gunnarsson B., Hedblom M., 2016. The effects of naturalness, gender, and age on how urban green space is perceived and used. Urban Forestry \& Urban, Greening, vol. 18, pp. 268-276.

Santos T., Mendes R.N., Vasco A., 2016. Recreational activities in urban parks: Spatial interactions among users. Journal of Outdoor Recreation and Tourism, vol. 15, pp. 1-9.

SaVVAS W., 2016. Green Infrastructure and Urban Biodiversity. Landscape Architecture Frontiers, vol. 4, no. 3, pp. 40-51.
SuÁrez-Varela M., Guardiola J., GonzálezGÓmez F., 2016. Do pro-environmental behaviors and awareness contribute to improve subjective well-being? Applied Research in Quality of Life, vol. 11, no. 2, pp. 429-444.

SuchoCKA M., 2013. Drzewo jako element zielonej infrastruktury. Problemy Ekologii Krajobrazu, vol. 36, pp. 85-94.

SzCzEPANOWSKA H.B. 2012. Miejsce terenów zieleni w strukturze zintegrowanego projektowania, zarzadzania i oceny ekologicznej inwestycji miejskich. Człowiek i Środowisko, vol. 36, no. 1-2, pp. 25-49.

Szulczewska B., Kaliszuk E., 2005. Problems of green structure planning and management in Warsaw. Final report Cost Action C11 - Green structure and urban planning, pp. 90-102.

Votsis A., 2017. Planning for green infrastructure: The spatial effects of parks, forests, and fields on Helsinki's apartment prices. Ecological Economics, vol. 132, pp. 279-289.

Wang Y., de Groot R., Bakker F., Wörtche H., LeEmans R., 2017. Thermal comfort in urban green spaces: A survey on a Dutch university campus. International Journal of Biometeorology, vol. 61, no. 1, pp. 87-101.

ZADROŻNIAK M., 2016. Jakość życia w mieście [in:] A. Nowakowska, Z. Przygodzki, A. Rzeńca (eds.), EkoMiasto - Społeczeństwo. Zrównoważony, inteligentny i partycypacyjny rozwój miasta, Łódź: Wydawnictwo Uniwersytetu Łódzkiego, pp. 22-38.

Žuvela-Aloise M., Koch R., Buchholz S., Früh B., 2016. Modelling the potential of green and blue infrastructure to reduce urban heat load in the city of Vienna. Climatic Change, vol. 135, no. 3-4, pp. 425-438. 
